\title{
Urinary tract infections treated with single dose of short-acting sulphonamide
}

\author{
GUNILLA KÄLLENIUS，JAN WINBERG
}

British Medical fournal, 1979, 1, 1175-1176

\section{Summary and conclusions}

In a prospective study 29 patients with urinary tract infections caused by sulphonamide-sensitive organisms were treated with a single oral dose of the short-acting sulphonamide sulphafurazole. Twenty-seven $(93 \%)$ of the 29 patients-and possibly all 29-were cured of their infections. There was no difference in the recurrence rates after single-dose treatment and treatment for 10 days or more. Six out of eight strains of Escherichia coli causing early recurrences were sensitive to sulphonamides.

These results suggest that uncomplicated infections may safely and successfully be treated by a single oral dose of a short-acting sulphonamide.

\section{Introduction}

Although urinary tract infections (UTIs) are common in children, especially girls, no well-documented guidelines exist about how long, how often, and in what doses treatment should be administered. Previously a rapid recurrence of UTI after treatment was thought to be caused by a remaining focus in the urinary tract and, for that reason, long-term treatment was preferred. It is now generally accepted that recurrences in most cases are reinfections with new organisms emanating from the faecal reservoir. ${ }^{1-3}$ The distinction between prophylaxis and treatment of a current UTI, therefore, must be emphasised. The correct duration of prophylaxis has been the subject of several studies. On the other hand, the minimal time needed to eradicate an acute UTI has not been sufficiently clarified. We undertook this study to see whether a single dose of a short-acting sulphonamide was efficient in eradicating non-febrile UTIs in girls in whom they recurred.

\section{Patients and methods}

We investigated 29 girls attending a urinary infection clinic who had a history of repeated symptomatic UTI. Their mean age was 10.4 years (range of 6-14). All had undergone intravenous urography, and none had scarring, stones, or obstruction. Five patients had vesicoureteric reflux grade I or II. The serum creatinine concentration did not exceed $120 \mu \mathrm{mol} / \mathrm{l}(1.4 \mathrm{mg} / 100 \mathrm{ml})$, and the renal concentrating capacity was $\geqslant 800 \mathrm{mmol}(\mathrm{mosmol}) / 1$. Patients with temperatures above $38^{\circ} \mathrm{C}$ or flank pain were not included in the study. The erythrocyte sedimentation rate (ESR) was below $10 \mathrm{~mm}$ in the first hour in 28 of the patients. In eight cases a C-reactive protein was obtained and proved negative. These investigations indicated that the infection was confined to the lower urinary tract.

\footnotetext{
Departments of Paediatrics, Huddinge and Karolinska Hospitals, Karolinska Institutet, S-104 01 Stockholm, and Department of Bacteriology, National Bacteriological Laboratory, S-105 21, Stockholm, Sweden

GUNILLA KÄLLENIUS, MD, paediatrician

JAN WINBERG, MD, professor
}

Infection was regarded as definite when two consecutive cleanvoided midstream specimens yielded a pure culture of the same organism in a concentration of over 100000 bacteria/ml of urine. Urinary leucocytes exceeded $50 \times 10^{6} / 1\left(50 / \mathrm{mm}^{2}\right)$ uncentrifuged urine in 18 patients.

\section{CLINICAL INVESTIGATIONS}

When infection was indicated by a positive urine culture of an organism sensitive to sulphonamide the patient was sent to the clinic, where a second specimen was taken for culture and the urinary leucocyte count and ESR were estimated. Each patient was given $200 \mathrm{mg}$ of sulphafurazole suspension $/ \mathrm{kg}$ body weight in a single oral dose. Sulphafurazole is a short-acting sulphonamide with a half life of six hours. Morning urine specimens were cultured daily at home during the next seven days using dipslides (Uricult, Orion Diagnostica, Helsinki, Finland); these were later read at the National Bacteriological Laboratory. Fourteen days later quantitative urine culture was performed.

\section{LABORATORY INVESTIGATIONS}

Urine specimens were cultured and bacterial counts performed with the standard loop technique. After speciation sensitivity tests were performed by the standardised disc diffusion method and the minimum inhibitory concentration (MIC) determined by the agar dilution method, ${ }^{5}$ using PDM-ASM agar (AB Biodisc, Solna, Sweden).

Serotyping-All Escherichia coli were serotyped by determining specific $\mathrm{O}$ antigens ${ }^{6}$ and the presence of $\mathrm{K}$ antigens. ${ }^{\text {? }}$

Biotyping-The API 20E test kit system was used (API System, France). The seven-digit profile was determined twice for all strains, with good reproducibility.

\section{Results}

All dipslide cultures performed during the first week showed little or no bacterial growth. At two weeks 10 cultures were positive. In eight of them the infections were caused by new strains or species (table I). Table II shows the results of serotyping and the API profile

TABLE I-Results of treating index infection with one oral dose of sulphafurazole

No of patients treated

No of positive cultures at two weeks New strains or species

Minimum No of patients cured of index infection

$\begin{array}{llll}. & . & & 29 \\ \therefore & \because & & 0 \\ \cdots & \cdots & 8 & 10^{*} \\ . & \cdots & 2 & \\ & . & & 27(93 \%)\end{array}$

*Verified by two cultures.

in the index infection and recurrences. In cases 14 and 23 both index infections and recurrences were caused by the same $E$ coli strain, as evidenced by the colony morphology, API pattern, and serology. This might indicate a recrudescence of the original infection, but since the recurrences occurred after seven negative dipslides had been obtained more probably they were reinfections. In case 26 the $E$ coli strains could not be typed before or after treatment. Their colony morphology and API patterns differed, however, so we assumed that they were different strains. Thus at least $27(93 \%)$ and possibly all of the 29 index infections were cured. 
TABLE II-Bacterial aetiology and sensitivity to sulphonamide in 10 patients with early recurrence

\begin{tabular}{|c|c|c|c|c|c|c|c|c|}
\hline \multirow{2}{*}{$\begin{array}{l}\text { Case - } \\
\text { No }\end{array}$} & \multicolumn{4}{|c|}{ Index infection } & \multicolumn{4}{|c|}{ Recurrence } \\
\hline & Species & Sensitivity & Serotype & $\begin{array}{c}\text { API 20E } \\
\text { 7-digit profile }\end{array}$ & Species & Sensitivity* & Serotype & $\underset{\text { 7-digit profile }}{\text { API } 20 \mathrm{E}}$ \\
\hline $\begin{array}{r}1 \\
2 \\
3 \\
7 \\
14 \\
17 \\
19 \\
23 \\
26 \\
28\end{array}$ & $\begin{array}{l}\text { Escherichia coli } \\
E \text { coli } \\
E \text { coli } \\
E \text { coli } \\
E \text { coli } \\
E \text { coli } \\
E \text { coli } \\
E \text { coli } \\
E \text { coli } \\
E \text { coli }\end{array}$ & $\begin{array}{l}\text { S } \\
\text { S } \\
\text { S } \\
S \\
S \\
S \\
S \\
S \\
S \\
S\end{array}$ & $\begin{array}{l}\text { 0NKN } \\
020 \mathrm{KN} \\
02 \mathrm{KI} \\
\text { 0NKI } \\
022083 \mathrm{KI} \\
013022 \mathrm{KN} \\
017077 \mathrm{KN} \\
0 \mathrm{NK3} \\
\text { 0NKN } \\
0120 \mathrm{KN}\end{array}$ & $\begin{array}{l}0144552 \\
5144572 \\
5144552 \\
4144552 \\
5144572 \\
1044552 \\
7044573 \\
5144552 \\
5144572 \\
1044552\end{array}$ & $\begin{array}{l}E \text { coli } \\
\text { Enterococci } \\
\text { Staphylococcus epidermidis } \\
E \text { coli } \\
E \text { coli } \\
E \text { coli } \\
E \text { coli } \\
E \text { coli } \\
E \text { coli } \\
E \text { coli }\end{array}$ & $\begin{array}{l}\text { S } \\
R \\
\text { ND } \\
\text { S } \\
\text { S } \\
\mathrm{R} \\
\mathrm{R} \\
\mathrm{S} \\
\mathrm{S} \\
\mathrm{S}\end{array}$ & $\begin{array}{l}07 \mathrm{KI} \\
\\
021 \mathrm{KN} \\
022083 \mathrm{KI} \\
\text { 0NKN } \\
01 \mathrm{KI} \\
\text { 0NK3 } \\
\text { ONKN } \\
\text { 0NKI }\end{array}$ & $\begin{array}{l}5144552 \\
\\
1144572 \\
5144572 \\
5144552 \\
5144512 \\
5144572 \\
1044552 \\
5144552\end{array}$ \\
\hline
\end{tabular}

- S = Sensitive (minimum inhibitory concentration $<32 \mu \mathrm{g} / \mathrm{ml}$ ). R = Resistant (minimum inhibitory concentration $>1024 \mu \mathrm{g} / \mathrm{ml}$ ). ND $=\mathrm{Not}$ done.

Table III shows when the infection first recurred after the singledose treatment. No reinfections occurred during the follow-up period in eight patients, of whom two were followed up for 31-180 days and six for 181 days or more. After the first recurrence patients were treated for 10 days. Management was then tailored to the individual, some patients being given prophylaxis for a longer period. The time lapse from the interruption of treatment or prophylaxis to the next recurrence was recorded. The infection recurred within two months of the interruption of treatment in $12(71 \%)$ out of 17 patients followed up. The corresponding numbers in whom the infection recurred after single-dose treatment were $15(52 \%)$ within two months and $21(72 \%)$ within one year (table III). Thus the shorter treatment did not increase he risk of early recurrence.

TABLE III-Time of appearance of first recurrence after single dose of sulphafurazole

\begin{tabular}{lccccccc}
\hline $\begin{array}{l}\text { Days after treatment } \\
\text { Cumulative No of } \\
\text { infected patients* }\end{array}$ & $0-7$ & $8-14$ & $15-30$ & $31-60$ & $61-90$ & $91-180$ & $181-360$ \\
\hline
\end{tabular}

*Each patient represented by only first recurrence.

A selection criterion for this study was that the organisms were sensitive to sulphonamides by conventional disc tests. MICs were less than or equal to $32 \mu \mathrm{g} / \mathrm{ml}$ for all the organisms giving the index infections. Of the reinfecting $E$ coli strains, two were resistant (MIC $>1024 \mu \mathrm{g} / \mathrm{ml}$ ) while the remaining six were sensitive $(\mathrm{MIC}<32$ $\mu \mathrm{g} / \mathrm{ml}$ ) (table II). The remaining two infections were caused by enterococci and Staphylococcus epidermidis.

\section{Discussion}

In this study 27 out of 29 patients-and possibly all 29-were cured of their infections by a single oral dose of a short-acting sulphonamide. Ten days of sulphonamide treatment is as effective as 60 days, and both regimens seem to eliminate cystitis as well as pyelonephritis in almost all patients. ${ }^{8}$. Single-dose treatment is apparently equally effective, at least in treating infections of cystitis type.

Another advantage of the ultra-short treatment with shortacting sulphonamides is that the effect on the faecal flora seems to be slight, since there were few recurrences with sulphonamide-resistant strains. This contrasts with the results of a previous study performed on hospital patients, in which all early recurrences were resistant after 10 days of sulphonamide treatment. ${ }^{10}$ Further advantages are the low incidence of side effects and low cost.

Charlton et al showed that a three-day course of amoxycillin was as effective as a 10 -day course ${ }^{11}$ in uncomplicated UTIs in women. Women with infections confined to the bladder were cured with a single dose of kanamycin injected intramuscularly, ${ }^{12}$ and single-dose treatment with amoxycillin has been successful in women with uncomplicated UTI. ${ }^{1314}$ Amoxycillin and kanamycin are considered to be bactericidal agents. The present study shows that even a bacteriostatic agent, such as a shortacting sulphonamide, administered in a single dose is effective in children.
Single-dose treatment with ultra-long-acting sulphonamides effectively eliminates infection. ${ }^{16} 16$ One reason for the satisfactory results of this study with a short-acting sulphonamide may be that urinary concentrations of sulphafurazole remain at a therapeutic level for about 36 hours (Källenius and Dornbusch, unpublished observations). With this kind of benign UTI the urine concentration is probably more important than the serum concentration.

Ronald et $a l^{12}$ found that failures with single-dose treatment were more common in infections affecting the kidney. One reason for this could be that pyelonephritic $E$ coli strains are more able to adhere to human uroepithelial cells than strains confined to the bladder ${ }^{17}$ and thus may be more likely to survive in the urinary tract during short-term treatment. We found that the infecting strains in this study adhered well to human periurethral cells ${ }^{18}$ but a comparison with pyelonephritic strains might show quantitative differences. Prolonged prophylactic treatment may lessen the risk of further infections, ${ }^{19}$ so shortterm treatment might increase the risk. In this study, however, there was no difference in the recurrence rate after single-dose treatment and treatment for 10 days or more.

We suggest that uncomplicated infections may safely and successfully be treated by a single oral dose of a short-acting sulphonamide.

We thank the personnel at the antibiotic section, department of bacteriology, National Bacteriological Laboratory, for all technical help, and Dr B Kaijser for doing the serotyping.

This study was supported by grant 19X-765 from the Swedish Medical Research Council.

Requests for reprints should be addressed to: Dr G Källenius, Department of Paediatrics, Karolinska Hospital, S-104 01 Stockholm, Sweden.

\section{References}

${ }^{1}$ Kunin, C M, Deutscher, R, and Paguin, A, Medicine, 1964, 43, 91.

2 Pryles, C, and Glagovsky, A, Pediatrics, 1965, 36, 219.

${ }^{3}$ Bergström, T, et al, fournal of Pediatrics, 1967, 71, 13.

4 Winberg, J, Larson, H, and Bergström, T, in Renal Infection and Renal Scarring, ed P Kincaid-Smith and K Fairyle, p 293. Melbourne, Mercedes, 1971.

${ }^{5}$ Ericson, H M, and Sherris, J C, Acta Pathologica et Microbiologica Scandinavica, 1971, suppl No 217.

6 Lidin-Janson, G, et al, fournal of Medical Microbiology, 1977, 10, 299.

7 Kaijser, B, et al, Lancet, 1977, 1, 663.

8 Bergström, T, et al, Acta Paediatrica Scandinavica, 1968, 57, 186.

9 Winberg, J, Bergström, T, and Jacobsson, B, Kidney International, 1975, 8, $\mathrm{s} 101$.

${ }^{10}$ Lincoln, K, Lidin-Janson, G, and Winberg, J, British Medical fournal, 1970, 3, 305.

11 Charlton, C A C, et al, British Medical fournal, 1976, 1, 124.

12 Ronald, A, Boutros, P, and Mourtada, H, fournal of the American Medical Association, 1976, 235, 1854.

${ }^{13}$ Leslie, S T, et al, New England fournal of Medicine, 1978, 298, 413.

14 Bailey, R R, and Abbott, G D, Nephron, 1977, 18, 316.

15 Grüneberg, R N, and Brumfitt, W, British Medical fournal, 1967, 3, 649

${ }_{16}$ Williams, J D, and Smith, E K, British Medical fournal, 1970, 4, 651.

17 Svanborg Edén, C, et al, fournal of Pediatrics, 1978, 93, 398.

18 Källenius, G, and Winberg, J, Lancet, 1978, 2, 540.

19 Smellie, J M, Katz, G, and Grüneberg, R N, Lancet, 1978, 2, 175.

(Accepted 8 March 1979) 